DE

\title{
Humanisation of the Subject in David Foster Wallace's Fiction: From Postmodernism, Avant-Pop to New Sensicerity? (Tri-Stan: I Sold Sissee Nar to Ecko, 1999)
}

\author{
Jaroslav Kušnír
}

Jaroslav Kušnír works at the University of Prešov, Prešov, Slovakia. His research focuses mainly on contemporary fiction, Australian literature and postcolonial writing. His publications include the monograph on Richard Brautigan and Donald Barthelme called Poetika americkej postmodernej prózy (2001) and several contributions to Slovak and foreign literary journals.

\begin{abstract}
David Foster Wallace's fiction is often considered to be an expression of the new American fiction emerging in the late 1980s, the authors of which expressed a certain distance from the dehumanised and linguistically constructed subject of postmodern fiction, and which depicted individuals influenced by mass media, pop culture and technology in technologically advanced American society. David Foster Wallace's short story Tri-Stan: I Sold Sissee Nar to Ecko (1999), however, was also included in the Avant-Pop Anthology (Larry McCaffery, L., eds. After Yesterday's Crash: The Avant-Pop Anthology. London, New York: Penguin, 1995). Some other critics (Adam Kelly, for example) consider him to be an author who expresses New Sincerity in his depiction of reality, which is a tendency in fiction trying to depict human experience and emotions through the use of language and which does not emphasise the human subject and experience to be a product of the interplay of signifiers as understood by Deconstruction criticism and many postmodern authors. This paper will analyse David Foster Wallace's use of narrative strategies that are connected with postmodern narrative techniques and, at the same time, the way they express a distance from them through a depiction of human experience as interactive communication between human subjects. In addition, the paper will analyse the poetics of the new sincerity as part of contemporary postpostmodern sensibility. That is why I use the term sensicerity to express a combination of the new sensibility and sincerity.
\end{abstract}

At least since the 1990s, critics and theorists have been discussing the end of postmodernism and postmodern literature based on a depiction of reality in which the human being is understood as a linguistic construct both influenced by and entrapped within it. These ideas were discussed during the Stuttgart seminar in Germany attended by leading postmodern authors and critics such as Raymond Federman, John Barth, Ihab Hassan and others in 1991 (see Ziegler, H.(ed.). The End of Postmodernism: New Directions: Proceedings of the First Stuttgart Seminar in Cultural Studies, 04.08.-18.08. 1991. Stuttgart : M \& P Verlag für Wissenschaft und Forschung, 1993). Moreover, postmodern critic Ihab Hassan continued to discuss the end of posmodernism in his other critical essays (see, for example, his "Beyond Postmodernism", 2003), and other critics suggested either a return to rather traditional narrative techniques (Versluys, 1992), or an emergence of a new sensibility based on a return 
to the spontaneity of childhood and childishness and a nostalgia for it, evanescence, and a direct participation of readers/watchers/internet users in the construction of meaning (digimodernism of A. Kirby, performativism of R. Eshelman and others) (Kirby, 2008).

In the 1990s, several critics identified an emerging tendency in American fiction represented by authors who wanted to separate from postmodern construction of the world by parodying or refering to postmodern narrative techniques in their own texts (James Rother writing about some of David Foster Wallace's, William Vollmann's, Richard Powers's works, postpostmodernism, etc.) (see, for example, Rother, "Reading the Riding the Post-Scientific Wave: The Shorter Fiction of David Foster Wallace", 1993, pp. 216-34), and by emphasising language as not deprived of meaning, as a pure sign system, but as a meanigful medium able to depict the humanity of a subject and its experience. Adam Kelly, for example, associates the fiction of David Foster Wallace, supposedly one of the main representatives of this new tendency in American fiction beginning in the late 1980s, with a new sincerity derived from Lionel Trilling's understanding of the term from his book on Sincerity and Authenticity. Lionel Trilling argues that "Society requires of us that we present ourselves as being sincere, and the most efficacious way of satisfying this demand is to see to it that we really are sincere, that we actually are what we want our community to know we are. In short, we play the role of being ourselves, we sincerely act the part of the sincere person, with the result that a judgement may be passed upon our sincerity that it is not authentic" (Trilling, 1982, p. 11). It seems Trilling suggests a certain split between sincerity and authenticity not only in the morality of the individual but also in literature. In his view, the concept of sincerity is based on the fact that "truth to the self is conceived of as a means of ensuring truth to the other" (Kelly, 2010, p. 132) which became "a salient, perhaps a definitive characteristic of Western culture for some four hundred years" (Trilling, 1982, p. 6). Trilling goes on to suggest that modernist and Beat literature as well as confessional poetry is authentic rather than sincere since it "conceives truth as something inward, personal and hidden, the goal of self-expression rather than other-directed communication" (Kelly, 2010, p. 132). In his study of David Foster Wallace fiction in the context of recent theories, Adam Kelly argues that "David Foster Wallace's fiction [...] asks what happens when the anticipation of others' reception of one's outward behaviour begins to take priority for the acting self, so that inner states lose their originating causal status and instead become effects of that anticipatory logic. Former divisions between self and other morph into conflicts within the self, and a recursive and paranoid cycle of endless anticipation begins, putting in doubt the very referents of terms life 'self' and 'other', 'inner' and 'outer'" (ibi., p. 136). It is this principle which implies, in Kelly's understanding, Trilling's concept of sincerity and which Kelly uses to describe David Foster Wallace's fiction, that is the fiction of "New Sincerity" (Kelly, 2010, p. 136) which depicts "truth to the self ... conceived of as a means of ensuring truth to the other" and as "other directed communication." Thus it seems David Foster Wallace's fiction is mostly understood as fiction representing a new tendency which differs from traditional postmodern narratives. But the position not only of David Foster Wallace's but also other contemporary postmodern writers' fiction is not always understood as fiction different from postmodernism. For example, a widely used Norton Anthology of Postmodern American Fiction includes David Foster Wallace's short story Lyndon as an example of postmodern fiction (Wallace in Geyh, eds. 1998).

Larry Mc Caffery and Mark Amerika, the authors of Avant-Pop Manifesto (Amerika online) suggest a new kind of literature emerging after postmodernism which is, in their view, heavily influenced by mass media and pop culture. In this Manifesto, they consider David Foster Wallace, but also writers included in the above anthology such as Mark Leyner, Ricardo Cortez Cruz, William Gibson, William Vollmann and Curtis White as representatives of this new kind of fiction. On the other hand, such writers who have traditionally been considered as 
postmodern writers (R. Sukenick, Paul Auster, Robert Coover, Don De Lillo, Raymond Federman and others) are included in the Avant-Pop Anthology of 1996 entitled After Yesterday's Crash: The Avant-Pop Anthology (1996) edited by Larry McCaffery. As can be seen from these comments, trying to identify new tendencies in American fiction reflecting the changing cultural atmosphere and sensibility of the past decade/s, the critics express quite contradictory views on the position of various contemporary authors in the context of both postmodern literature and innovative tendencies following it. What is important and what has contributed to the ambiguity of these views is, in my view, the fact that there is in all these authors a strong connection with the postmodernism and postmodern narrative techniques they use, refer to, transform, parody, cite or overtly undermine. The Avant-Pop manifesto, for example, clearly states the death of postmodernism but, at the same time, admits postmodernism's influence on Avant-Pop literature expressing the sensibility of what they call "Mediagenic reality" marked by a dominance of mass media influencing human thinking, behaviour, and "a more sensual, trippy, exotic and networked Avant-Pop experience" (Amerika online). At the same time, they emphasise the idea of collective authorship in which meaning is created through a mutual interaction between different authors and media: "Instead, the future of writing will feature more multi-media collaborative authoring that will make itself available to hundreds if not thousands of potential associates around the world who will be actively internetworking in their own niche communities" (Amerika online).

David Foster Wallace's short story Tri-Stan: I Sold Sissee Nar to Ecko is included in the abovementioned Avant-Pop anthology but definitely uses postmodern narrative techniques such as both reference to and modification of various ancient, medieval and contemporary myths through the use of intertextuality (the myths such as Echo and Narcissus, Tristan and Isolde, contemporary TV shows, etc.), a parody of commercial brand names, unclear, fragmented narrators, ovelapping of reality, fiction and media TV shows), language games, play with language and its referential function, and so on. On the other hand, the story gives a chaotic and complicated, at some points even almost a nonsensical "image" of reality based on a fragmented, chaotic narrative or rather on an interaction between narrators and different fragments from media and reality. The narrators are mostly exclusively extreme parodic versions of the narrators who have traditionally functioned as reliable recorders of reality, for example chroniclers and historians whose narratives or their fragments are commented on by other fragmentary narrators. This strategy creates a metafictional effect which makes the reader doubt the objectivity of related events but which also presents characters not as real human beings but rather as linguistic or media constructs entrapped in the sign system of language and media that is a quite typically postmodern representation of reality, which is in keeping with Jacques Derrida's idea that "there is nothing outside the text" (Derrida, 1976, p. 158-59). In other words, this principle and vision of the world emphasises the fictiousness rather than human nature of characters and makes the reader realise the difference between reality and its linguistic representation which, as I have mentioned, creates this metafictional effect (Patricia Waugh) and emphasises an ontological dominant which, in Brian McHale's understanding, is characteristic of the postmodern vision of the world (McHale). It can be seen at the very beginning of the story when one of the narrators is introduced: "The fuzzy Hensonian epiclete Ovid the Obtuse, syndicated chronicler of trans-human entertainment exchange in low-cost organs across the land, mythologizes the origins of the ghostly double that always shadows human figures on UHF broadcast thus:" (Wallace, 1999, p. 200).

This radical linguistic play associated with the narrator is based on exaggeration and radical parody of names of famous personalities in science, philosophy, and art (Ovid) who become rather brand names commercialised through media now connected with entertainment rather than with serious science. The narrator's status tradionally understood as that of a serious and reliable chronicler is undermined by his position as "a syndicated chronicler", which implies 
his connection with business, entertainment and the commercialisation of culture resulting in consumerism related to the media and entertainment industry. Thus, in addition to the postmodern depiction of the human being and his/her status as a linguistic construct within the sign systems of language and media, a parody of contemporary culture implies a critique of postmodern consumerism, commercialisation of life but also of a dehumanisation of the human subject. David Foster Wallace further develops fragmented, chaotic and, at some points, seemingly nonsencial stories through the depiction of Agon M. Nar, head of Recombinant Programming at Tri-Stan Entertainment and founder of the Satyr-Nymph Network; his three daughters, Sissee Nar, aspiring thespian and star of Beach Blanket Endymion, Leigh Nar and Coleptic Nar, USC cheerleaders; and other characters such as" Ecko of Venice...Recombinant Head of all Tri-Stan" (Wallace, 1999, p. 201); Gods such as StatisGod of Passive Reception, Chairman of the Board of Sturm-Drang; Herm Afro Deight, M.D., God of Surgical Enhacement; Sisboomba, the Padded Gods; or, for example, CodependaeStasis's S.O., Queen Goddess of the fluorescent basin. Different fragmented narratives mostly depict various chases, loves and intrigues; commercial, company and syndicate relationships which imply various variations of myths such as Tristan and Isolde, or Echo and Narcissus; combinations of popular TV shows which create the image of reality as becoming a distorted version of these and other myths and ideas commercialised through media and pop-culture that people have become the consumers of. The parodic and fragmented story of Agon M. Nar as narrated by Ovid the Obtuse is introduced in the following way:

"There moved \& shook, Before Cable, a wise\&clever programming executive named Agon M. Nar. This Agon M. Nar was revered throughout medieval California fluorescent basin for the clever wisdom\&cojones with which he presided over Recombinant Programming for the Telephemus studios division of Tri-Stan Entertainment Unltd. Agon M. Nar's Programming archè was the metastasis of originality. He could shuffle\&recombine proven entertainment formulae that allowed the muse of Familiariaty to appear cross-dressed as Innovation. Agon M. Nar was also a devoted family man.\& so it came to pass that, as his Brady Bunch\&All in the Family flourished\&begat Family Ties\&Diff'rent Strokes\&Gimme a Break\&Who's the Boss?, from whose brows, hydra-like, sprang Webster\&Mr. Belvedere\&Growing Pains\&Married... With Children\&Life Goes On\&the mythic Cosby, all with ads infinitum, Agon M. Nar in private family life did beget three semi-independent vehicles, daughters, maidens, Leigh\&Coleptic\&Sissee, who did then grow\&thrive like kudzu among the fluorescent basin's palms\&malls\&beaches\&temples" (Wallace, 1999, p. 200).

This parodic and fragmented narrative becomes rather a series of TV shows and other names juxtaposed to seemingly real names of human beings (Agon Nar and his daughters) and terms referred to and used by deconstructionist and postmodern critics such as, for example, archè. All these names lose their original meaning and become only dehumanised commercial brand names and linguistic signs, which implies David Foster Wallace's critique of consumerism and commercialism through his use of parody (his daughters referred to as vehicles, programming archè, etc.). In his well-known essay E. Unibus Pluram: Television and US. Fiction, David Foster Wallace argues that irony as well as earlier the generation of postmodern writers such as John Barth, Thomas Pynchon and Robert Coover who used irony as a radical means of critique have lost their radicalness and critical function because of the influence of television and media which started to use irony and some postmodern techniques in advertising and TV programmes, and because of the institutionalisation of these authors' fiction by universities which, in his view, requires a different kind of fiction which would reflect this situation (Wallace, 1997, pp. 21-82). In the above passage, not only postmodern critique of media and popular culture is depicted, but David Foster Wallace also implies both contemporary sensibility by a depiction of this commercialisation and institutionalisation (archè, sturm\&drang, etc.) and an awareness of the inadequacy of postmodern representation 
of the world from which he expresses a distance. Thus his story becomes closer to the sensibility some critics refer to as post-postmodern or digimodernist (A. Kirby. J. Burns, N. Timmer). This sensibility rejects postmodern irony as a means of critique and tries to recuperate a possibility of representation of the human experience and the human subject as living organisms rather than linguistic constructs and a sign system as the earlier generation of postmodern authors suggested. In her study of David Foster Wallace's and other contemporary American authors' fiction, Nicole Timmer writes, in connection with these authors' fiction, about a re-humanisation of subjectivity and about a "transformation of postmodern subjectivity" (Timmer, 2010, p. 18). As Timmer further observes, "Most notable in the work of this younger generation of writers is the emphatic expression of feelings and sentiments, a drive towards inter-subjective connection and communication [...] Their texts perform a complicit and complicated critique on certain aspects of postmodern subjectivity, especially on the perceived solipsistic quality of the subjective postmodern experience world, and envision possible reconfigurations of subjectivity that can no longer be framed [...] as 'postmodern"', (Timmer, 2010, p. 13).

In this sense then David Foster Wallace's short story is close to Avant-Pop authors mentioned above because of the emphasis on popular culture which is depicted as connected with everyday experience. At the same time, however, his short story is also connected with the concept of sincerity as understood by Trilling and Kelly, especially because of constant interaction and dialogue between narrators and fragmented narrative voices which express an interest in communication with the other and undermine the singularity of self-expression directed inward, that is what Lionel Trilling understood as a characteristic of authenticity, for example, for Modernist literature, confessional poetry, the Beat authors, etc. At the same time, interaction and fragmented dialogues between different narrators, fragments of reality and media express Wallace's interest in human communication, "a drive towards inter-subjective connection and communication" (Timmer, 2010, p.13). Moreover, David Foster Wallace's short story is deeply rooted in the postmodern world, popular culture, media, commercialism and technology, the world his short story gives a critique of. That is why in the title of this paper I have used the term sensicerity as a combination of (postmodern) sensibility and sincerity in Trilling's understanding to refer to David Foster Wallace's depiction of a new sensibility which is different from the traditional postmodern vision of the world and which shows his interest in intersubjective communication as a humanising tendency in fiction.

\section{Works cited:}

Amerika, M. 2014. "Avant-Pop Manifesto. Thread Baring Itself in Ten Quick Posts." $<$ http://www.altx.com/manifestos/avant.pop.manifesto.html> February 20, 2014

Derrida, J. 1976. Of Grammatology. Baltimore: Johns Hopkins University Press.

Geyh, P., Leebron, F. G.,Levy, A.(eds.). 1998. Postmodern American Fiction. A Norton Anthology. New York: Norton.

Hassan, I. 2003. "Beyond Postmodernism: Toward An Aesthetic of Trust". In Angelaki, 8:1 pp. 3-11. 
Kelly, A. 2010. "David Foster Wallace and the New Sincerity in American Fiction." In Hering, D.(ed.). Consider David Foster Wallace. Critical Essays. L.A., Austin: Sideshow Media Group Press, pp.131-146.

Kirby, A. 2009. Digimodernism: How New Technologies Dismantle the Postmodern and Reconfigure Our Culture. London: Continuum.

McCaffery, L. 1995. After Yesterday's Crash. The Avant-Pop Anthology. London, NewYork: Penguin.

McHale, B. 1987. Postmodernist Fiction. New York: Methuen.

McHale, B. 2007. "What Was Postmodernism?” In Electronic Book Review. December 20, 2007. http://www.electronicbookreview.com/thread/fictionspresent/tense.

Rother, J. 1993. "Reading the Riding the Post-Scientific Wave: The Shorter Fiction of David Foster Wallace." In The Review of Contemporary Fiction 13, No. 2, pp. 216-34.

Timmer, N. 2010. Do You Feel It Too? The Post-Postmodern Syndrome in American Fiction at the Turn of the Millennium. Amsterdam- New York: Rodopi.

Trilling, L. 1971. Sincerity and Authenticity. London, Cambridge, Mass.: Harvard University Press,. Versluys, K. (ed.). 1992. Neo-realism in Contemporary American Fiction. Amsterdam, Atlanta, GA: Rodopi.

Wallace, D. F. 1999. Brief Interviews with Hideous Men. Boston, New York, London: Little, Brown and Company.

Wallace, D. F. 1997. A Supposedly Fun thin I'll Never Do Again. Boston, New York, London: Little, Brown and Company.

Waugh, P. 1984. Metafiction: The Theory and Practice of Self-Conscious Fiction. London: Routledge,.

Jaroslav Kušnir

University of Prešov

Prě̌ov

Slovakia

jkusnir@fhpv.unipo.sk

Tento príspevok je súčastou riešenia grantového projektu VEGA č. 1/0858/12 Od postmoderny k novej senzibilite v literatúrach anglicky hovoriacich krajín. 